\title{
ANALYSIS OF COPING STRATEGY IN OVERCOMING LACK OF FOOD IN COASTAL COMMUNITY HOUSEHOLDS IN LANTAGI VILLAGE, KULISUSU SUB DISTRICT NORTH BUTON DISTRICT
}

\author{
Arif Rahman ${ }^{1)}$, Muhammad Aswar Limi ${ }^{1)}$, Samsul Alam Fyka ${ }^{\left.{ }^{*}\right)}$ \\ ${ }^{1}$ Department of Agribusiness, Faculty of Agriculture, Halu Oleo University Kendari 93232 \\ ${ }^{*}$ Corresponding author : samsulalamfyka85@gmail.com
}

To cite this article:

Rahman, A., Limi, M., \& Fyka, S. (2021). Analysis of Coping Strategy in Overcoming Lack of Food in Coastal Community Households in Lantagi Village, Kulisusu Sub District North Buton District. JIA (Jurnal IImiah Agribisnis) : Jurnal Agribisnis dan IImu Sosial Ekonomi Pertanian, 6(1), 1 - 10. doi:http://dx.doi.org/10.37149/jia.v6i1.15968

Received: January 11, 2021; Accepted: February 14, 2020; Published: February 21, 2020

\begin{abstract}
This study aims to determine Coping Strategy Analysis in Overcoming Deficienciesfood carried out by coastal community households in Lantagi Village, Kulisusu District, North Buton Regency. The research was conducted from January to March 2020 in Lantagi Village, Kulisusu District, North Buton Regency. The population in this study amounted to 175 households and the sample was taken by simple random sampling using the Slovin formula, namely 35 households. Coping Strategy Analysis in Overcoming Deficiencies household food using the Shariff and Khor approach which is divided into two categories, namely strategies related to food and strategies related to income or expenditure. The results showed that households in Lantagi Village, Kulisusu District, North Buton Regencyin The strategy to overcome food shortages related to food, the main strategy to be carried out is to reduce the portion of food and purchasing cheaper foodstuffs (substitution) by $77.1 \%$ and strategies related to household income or expenditure the main strategy is a strategy to reduce cigarette consumption by $65.7 \%$.
\end{abstract}

Keywords: coastal communities; coping strategy; household; lack of food

\section{INTRODUCTION}

Coastal communities are a group of people living in coastal areas who live together and meet their daily needs from resources in the coastal areas. People who live in cities or coastal settlements have socio-economic characteristics that are closely related to the economic source of the sea area. Likewise, types of livelihoods that utilize natural resources or environmental services in coastal areas, such as fishermen, fish farmers, and maritime industry owners or workers. Coastal communities that are dominated by fisheries are generally still at the poverty line, they have no choice of livelihood, have low levels of education, do not know and are aware of the preservation of natural resources and the environment.(Lewaherilla, 2002).

People who live in coastal areas are fishermen who have an economic life related to marine resources. Fishermen as the dominant coastal community have a low level of welfare because they face poverty problems. According to Sipahelut in(Sofianto, 2018) Coastal communities, especially fishermen are closely related to poverty, are even called the poor among the poor.

Budiharsono (2009) in (Natalia \& Alie, 2014) said that development in coastal areas is relatively left behind compared to other land areas so that coastal communities are relatively poorer than other areas.

From the results of preliminary observations it is known that the coastal communities in Lantagi Village have been working as fishermen for generations, like fishermen in general, their income is influenced by, among others, weather conditions, the technology used and the range of fishing. In addition to their livelihoods as fishermen, some people in Lantagi Village also work as farmers, but the agricultural yields they get are still very low, different from other areas because the area is filled with rocks that exist throughout the village. They only use agricultural land between the 
gaps in the rock, but the plants that grow in the area are thin and stunted due to the few nutrients available. so that the plant cannot grow properly. The coastal communities in Lantagi Village are forced to use the land to obtain food because they do not have any land in other areas.

The coastal community in Lantagi Village in adapting themselves to geographical conditions with only livelihoods as fishermen and farming. Limited land both in terms of quantity land (narrow land) as well as land quality which is generally dry land and rocky, so that people rely on farming and fishermen. The description shows that generally agricultural land is in the location research is included in the category of marginal land. Actually, marginal land is included Land that cannot be used for agriculture because it is land that is not productive (Anderson, 2012) in (Massalinri et al., 2017). The limited land is a very influential factor in activities community economy. The choice of commodity taken is only an alternative as a form of community adaptability to the environment. Fishermen, as the main livelihood of the community, also have limitations in terms of season and fishing gear used is still very traditional. Fishing gear used is only fishing rods, trawlers, spears and arrows the number of catches is still very limited.

Based on the description above that the fishermen in the village of Lantagi are fishermen who are still in the category of small fishermen who are characterized by still low technology in the fishing gear used. Based on the dominant livelihood of the people in the village of Lantagi in above, in order to fulfill the need, especially food, it is very limited. This matter This is due to the fact that there is limited production land as well as the catchment area and fishing gear used.

According to (Sumarsono \& Muslikah, 2017) The level of food insecurity can be viewed from (1) the side of food production, namely the ability to produce food for make ends meet. (2) The distribution process does not match the existing demand and supply so that food becomes scarce (3) Consumption, from this aspect, for example the community cannot afford to buy less purchasing power or because of poverty.

According to previous research conducted by (Laoh \& Tangkere, 2018), in his research entitled analysis of income and consumption of coastal communities (Case Study: In Rarumis Hamlet, Karor Village, East Lembean District) in the results of his research said that The people on the coast are still in a weak economy that is not yet feasible, because the income they earn has not been able to meet their wants and consumption, then continued by research (Kuwornu et al., 2013) in his research entitled comparative analysis of food security status of farming households in the coastal and the forest communities of central region of Ghana (comparative analysis of household agricultural food security status in coastal areas and forest communities in central Ghana), the results of his research stated that In determining the household food security status of respondents using the GSS standard (2000) of $2900 \mathrm{kcal}$, the results reveal that the majority of respondents are food insecure. The results further show that farmer households in forest areas are less vulnerable to food than their counterparts in coastal areas. So based on the description above the purpose of this study is to find outcoping strategy in Overcoming Household Food Shortages in Coastal Communities in Lantagi Village, Kulisusu District, North Buton Regency

\section{MATERIALS AND METHODS}

The location of this research is in Lantagi Village, Kulisusu District, North Buton Regency from January to March 2020. The location of this study was chosen purposively and the sampling method used the Slovin method. The population in this study were all coastal community households in Lantagi Village, whose main job was as farmers and fishermen, amounting to 175 families with a total population of 628 people and the sampling method using the Slovin method in order to obtain a research sample of 35 families. Analysis of the data used in the purpose of this study is about coping strategy using an approach (Shariff \& Khor, 2008) which divides coping strategies into two categories, namely (i) strategies related to food and (ii) strategies related to income and expenditure. Examples of food-related strategies are reducing food portions and reducing the frequency of meals. Examples of strategies related to income and expenses are selling assets and borrowing money from families. The answers to the questions will be divided into "yes" and "no". Data will be analyzed with descriptive statistics in the form of percentages and averages.

\section{RESULTS AND DISCUSSION}

\section{Overview of Respondents}

The general description of respondents in the Lantagi Village, Kulisusu District, North Buton Regency includes: Age, education, number of family members, income, business experience, and land ownership. The explanation is as follows: 
Age

Broadly speaking, the population of a country can be divided into two groups, namely workers and non-workers. The population is classified as a workforce if the population has entered the working age. The age limit for working in Indonesia is 15 - 64 years old. Meanwhile, residents who are less than 15 years old and more than 64 years old are not included in the workforce group(Prajnaparamita, 2018). Based on this, it can be concluded that the productive age is at the age of 15-64 years provided that students, students, housewives, and people with special needs are not included in the labor category.

Table 1. Respondent household identity by age in Lantagi Village, Kulisusu District, North Buton Regency

\begin{tabular}{cccc}
\hline No. & Age group (Year) & Number of Respondents & Percentage (\%) \\
\hline 1 & $15-64$ & 28 & 80 \\
2 & $\geq 64$ & 7 & 20 \\
\hline & Total & 35 & 100 \\
\hline
\end{tabular}

Table 1 shows that households in Lantagi Village with more productive age are 28 people $(80$ percent) than households with non-productive age, namely 7 people (20 percent). Productive age still has physical abilities that are stronger and more agile in doing a job. Besides that, the productive age group also easily accepts new innovations in society compared to the non-productive age. So that in this case the ability to meet food security can be done well compared to non-productive ages. However, the non-productive age does not even rule out being able to match or even compete with the younger ones, namely by having high enthusiasm and more experience than those who are still young.

\section{Level of education}

Education level is a level of education that has been passed or completed by coastal communities. Education levels range from not attending school, not completing elementary school, elementary school, junior high school, high school and college. The education level of respondents can be seen in table 2, below.

Table 2. Number of respondents based on the level of formal education of family heads in Lantagi Village, Kulisusu District, North Buton Regency

\begin{tabular}{clcc}
\hline No. & \multicolumn{1}{c}{ Level of education } & Number of Respondents & Percentage $(\%)$ \\
\hline 1 & No school & 20 & 57.1 \\
2 & Not completed in primary school & 4 & 11.4 \\
3 & Primary school & 5 & 14.2 \\
4 & Junior high & 4 & 11.4 \\
5 & High school & 2 & 5.8 \\
6 & S1 & - & 0.0 \\
\hline \multicolumn{2}{r}{} & 35 & 100 \\
\hline
\end{tabular}

Table 2 shows that the education of the head of the respondent's family in Lantagi Village is still very low, this can be seen from the education level of respondents who did not go to school as many as 20 respondents (57.1 percent) that is more than half of the total number of respondents. Then added more respondents who did not complete primary school, namely 4 respondents (11.4 percent) and the level of elementary education equivalent to 5 people (14.2 percent). Meanwhile, for junior high school (SMA) education level, there were only 2 respondents (5.8 percent) and there were no graduates for the head of family in Lantagi Village.

Table 3 shows that the education level of the respondent's wife / housewife is still very low because there are still many respondents who do not go to school, namely 18 respondents $(51.4$ percent) and those who do not complete elementary school, namely 5 respondents (14.2 percent). Meanwhile, for elementary education, there are 4 respondents, with 6 years of education, junior high school education with 3 respondents with 9 years of education, and high school education level with 4 respondents with 12 years of education. Whereas for undergraduates there is only 1 respondent with a length of education over 12 years. 
Table 3. Number of respondents based on the level of formal education of wife / housewives in Lantagi Village, Kulisusu District, North Buton Regency

\begin{tabular}{|c|c|c|c|}
\hline No. & Level of education & Number of Respondents & Percentage(\%) \\
\hline 1 & No school & 18 & 51.4 \\
\hline 2 & Not completed in primary school & 5 & 14.2 \\
\hline 3 & Primary school & 4 & 11.4 \\
\hline 4 & Junior high & 3 & 8.6 \\
\hline 5 & High school & 4 & 11.4 \\
\hline 6 & S1 & 1 & 2.9 \\
\hline & Total & 35 & 100 \\
\hline
\end{tabular}

The education level is a description of the education levels that have been completed by the community. Community education is widely cited as one of the factors for accelerating the drive for community development. Through education, technology adoption and active participatory development, including in business planning and development. Education also has a relationship with consumption, as according toRahardja et, al. (2005) in(Karmini \& Erwin, 2012), the higher a person's education, the higher the consumption expenditure will be, thus affecting consumption patterns and a positive relationship. When a person or family has a high level of education, the necessities of life are increasing. This condition is caused because what they have to fulfill is not only the need for food and drink, but also the need for information, good association in society, and the need for other people's recognition of their existence. Meanwhile, according to (Fatimah, 1995) said that a high level of education will increase the awareness of housewives to seek as much information as an effort to make the family prosperous, including information about food and nutrition.

\section{Number of Family Members}

The large number of family members is closely related to the need for food / food, because the greater the number of family members, the greater the need for food / food. (Hariyani, 2016), explains that the relationship between the number of household members and food consumption is that the larger the household size, the less available food that can be distributed to each household member, so that less food is consumed. Based on the number of household members, the size of the household is grouped into two, namely small and large households. According to(Sabono et al., 2019), argues that those belonging to small families are around 2-4 people, while family members $\geq 4$ people are included in large families.

Table 4. State of respondents based on number of family members in Lantagi Village, Kulisusu District, North Buton Regency

\begin{tabular}{cccc}
\hline No. & Number of Family Members (People) & Number of respondents & Percentage (\%) \\
\hline 1 & $<2$ & 2 & 5.7 \\
2 & $2-4$ & 21 & 60 \\
3 & $>4$ & 12 & 34.2 \\
\hline & Total & 35 & 100 \\
\hline
\end{tabular}

Table 4 shows that the number of family members with dependents alone or one person is 2 respondents. Meanwhile, the number of dependents 2-4 people is 21 people (60 percent). Respondents with a number of family members as many as 5-7 people are 11 people (31.4 percent), and for the number of family members of more than 7 people is only 1 respondent with a percentage of $2.8 \%$ of the total number of respondents.

The number of family members greatly determines the number of family needs. The more family members, the more family needs that must be met. Vice versa, the fewer family members means the less needs the family must fulfill. So that in a family with a large number of members, many needs will be followed(Karmini \& Erwin, 2012). The larger the household size means that there are more household members, which in the end will be heavier for the household to fulfill their daily needs. Likewise, the number of children insured in the family and family members who are disabled or elderly will have an impact on the size of a family's expenses. They cannot support themselves so they depend on the head of the family and his wife. Children who are not yet adults need to be helped with the cost of education, health care and other living expenses (Karmini \& Erwin, 2012).

The number of family dependents is one of the factors affecting household consumption patterns. The number of family members, the more varied the consumption pattern because each member of the household does not necessarily have the same taste. The number of family members 
is related to household income which in turn will affect the household consumption pattern (Karmini \& Erwin, 2012).

\section{Household Income}

Needs and wants are unlimited in number, it's just that these needs and wants are limited by the amount and income that a person receives. The income received by the community is certainly different from one another, this is due to the different types of work they do. The difference in employment is motivated by the level of education, skill,and experience at work. The level of welfare indicators in society can be measured by the income it receives.

The increase in people's standard of living can be illustrated by the increase in yield real incomeper capita, while the standard of living is reflected in the level and pattern of consumption which includes elements of food, health, housing and education to maintain a reasonable human degree. Then obey(Hanum, 2017) states that the relationship between income and consumption is a unidirectional relationship (proportional) means the income higher can lead to expenditure consumption is greater and so too the opposite is when the income level is low hence consumption expenditure is also low. Based on the classification according to the Central Bureau of Statistics, income is divided into four groups, namely the very high income group, namely the average income of more than Rp. 3,500,000 per month. High income group if the average income is between IDR $2,500,000$ - IDR 3,500,000 per month. Medium income group if the average income is between IDR $1,500,000$ - IDR 2,500,000 per month. And low income groups are less than IDR 1,500,000 per month. Household income in Lantagi Village, Kulisusu District, North Buton Regency can be seen in table 5 below:

Table 5. Number of respondents according to average household income in Lantagi Village, Kulisusu District, North Buton Regency

\begin{tabular}{cccc}
\hline No. & Total income (IDR) & Number of Respondents & Percentage (\%) \\
\hline 1 & $>3,500,000$ & 1 & 2.8 \\
2 & $>2,500,000-3,500,000$ & 0 & 0.0 \\
3 & $>1,500,000-2,500,000$ & 0 & 0.0 \\
4 & $<1,500,000 \quad$ Total & 34 & 97.1 \\
\hline \multicolumn{2}{c}{ Tol } & 35 & 100 \\
\hline
\end{tabular}

Table 5 shows that household income in Lantagi Village is still in the low category, this can be seen in the table where the household income is dominated by 34 family heads with an income of less than 1,500,000 (97.1 percent), then only very high income. there is 1 respondent (2.8 percent). Meanwhile, for high and medium income, none of the respondents ( 0.0 percent).

In essence, the income received by a person or business entity is certainly influenced by many factors, such as the level of education and experience of a person, the higher the level of education and experience, the higher the level of income, then the level of income is also strongly influenced by working capital, working hours, access. credit, number of workers, family dependents, types of merchandise (products) and other factors. In general, people are always looking for a high level of income to meet their household needs, but this is limited by a number of these factors(Widiastuti, 2018).

\section{Business Experience}

Business Experience is one of the most important factors in carrying out an activity, job or activity in our daily life, because people who have experience in trying more easily overcome various problems that arise in carrying out a business activity because they have learned from previous experiences. has been through. According to Soeharjo and Patong in(Limi, 2015) that business experience will be said to be experienced if they have been in the business for 5-10 years, while 10 years and over are categorized as experienced and less than 5 years are categorized as less experienced.

The respondent's household business experience in Lantagi Village can be seen in table 4.9 below. However, tables 6 shows that the business experience is related to the business of each head of the respondent's family that they are involved in, consisting of fishermen and farmers. For more details, see table 4.9 below: 
Table 6. Distribution of respondents based on business experience in Lantagi Village, Kulisusu District, North Buton Regency

\begin{tabular}{cccc}
\hline No. & $\begin{array}{c}\text { Experience Category } \\
\text { Business (Year) }\end{array}$ & Number of Respondents & $\begin{array}{c}\text { Percentage } \\
(\%)\end{array}$ \\
\hline 1 & $(\leq 5)$ & 8 & 22.8 \\
2 & $(6-10)$ & 6 & 17.1 \\
3 & $(\geq 10)$ & 21 & 60 \\
\hline & & 35 & 100 \\
\hline
\end{tabular}

Table 6 This shows that the respondents' business experience is predominantly in the very experienced category with 21 people (60 percent). Meanwhile, 8 people (22.8 percent) had less experience and 17.1 percent experienced. The dominant business experience possessed by the respondent's household in Lantagi Village can help and make it easier to carry out their work or activities. because with this experience, they can read and predict situations that will occur in the field so that they can overcome the risks of failure that exist.(Wahyuni et al., 2015) argues that experience in running a business is the best predictor of success, especially if the new business is linked to previous business experience.

\section{Ownership of Agricultural Land}

Ownership of agricultural land is one of the assets that can be used by the community in providing food independently. The availability of agricultural land owned by coastal communities is expected to be able to be used as gardens or arable land that can be planted with various types of agricultural plants so that they can support household food availability. The number of respondents' land ownership can be seen in table 7, below.

Table 7. Number of respondents by land ownership in Lantagi Village, Kulisusu District, North Buton Regency

\begin{tabular}{ccccc}
\hline No. & & Owning land (Yes or No) & Number of Respondents & Percentage (\%) \\
\hline 1 & Yes & & 21 & 60 \\
2 & No & & 14 & 40 \\
\hline & Total & 35 & 100 \\
\hline
\end{tabular}

Table 7 shows that respondents in Lantagi Village dominantly own agricultural land, namely 21 people (60 percent), and 40 percent who do not own land. With this land, it can support the availability of food in the village of Lantagi, if the land can be used properly. However, the land in Lantagi Village is not very supportive, where the topography of the land is very full of rocks throughout the village so it is not suitable for agricultural areas. however, the farming community continues to use the land because there is no more land owned by the community other than that land to meet their daily needs. Plus the type of livelihood in Lantagi Village is limited, where there are only two types of work involved, namely fishing and farming. However, based on the results of the respondents' interviews, some households who have worked as farmers for a long time or have been working as farmers since starting their jobs as farmers, they do not know their livelihoods as fishermen due to lack of experience, plus the economic limitations of the farming community so they cannot make or buy fishing tools such as boats, ketinting, nets, fishing tools and others. Meanwhile, those who work or work part of the way as fishermen want to grow food but they don't own the land. Some households who have worked as farmers for a long time or have started their work as farmers, they do not know their livelihoods as fishermen due to inexperience, plus the economic limitations of the farming community so they cannot make or buy fishing tools such as boats, ketinting, nets, fishing tools and others. Meanwhile, those who work as fishermen want to grow food but they do not own the land. Some households who have worked as farmers for a long time or have started their work as farmers, they do not know their livelihoods as fishermen due to inexperience, plus the economic limitations of the farming community so they cannot make or buy fishing tools such as boats, ketinting, nets, fishing tools and others. Meanwhile, those who work as fishermen want to grow food but they do not own the land. In addition, the economic limitations of the farming community so that they cannot make or buy fishing tools such as boats, ketinting, nets, fishing tools and others. Meanwhile, those who work as fishermen want to grow food but they do not own the land. In addition, the economic limitations of the farming community so that they cannot make or buy fishing tools such as boats, ketinting, nets, fishing tools and others. Meanwhile, those who work as fishermen want to grow food but they do not own the land. 


\section{Coping Strategy}

In this study, the coping strategy used in overcoming food shortages is divided into two, namely: (1) strategies related to food and (2) strategies related to household income or expenditure.

\section{Strategies Related to Food}

Food is the most essential basic need for humans to sustain life and life. Food as a source of nutrients (carbohydrates, fats, proteins, vitamins, minerals and water) is the main foundation for humans to achieve health and well-being throughout the life cycle. Food is a basic human need, so we cannot be separated from the name food, however, in a household we must have a strategy related to food, from food availability, food affordability, food utilization, and food stability so that food needs can be fulfilled. well. The strategies related to food carried out by households in Lantagi Village can be seen in table 8.Strategies related to food in overcoming food shortages carried out by households vary widely, from reducing food portions to prioritizing food to certain family members which consists of ten (10) strategies

Table 8. Number of respondents according to food-related strategies taken in overcoming food shortages

\begin{tabular}{clcc}
\hline No. & \multicolumn{1}{c}{$\begin{array}{c}\text { Related Strategies } \\
\text { Food }\end{array}$} & $\begin{array}{c}\text { Amount } \\
\text { Respondents }\end{array}$ & $\begin{array}{c}\text { Percentage } \\
(\%)\end{array}$ \\
\hline 1 & Reducing food portions & 27 & 77.1 \\
\hline 2 & Buying cheaper foodstuffs (substitution) & 27 & 77.1 \\
\hline 3 & Switching staple foods (such as from rice to cassava) & 26 & 74.2 \\
\hline 4 & $\begin{array}{l}\text { Cooking food / what food is available at home (eating as little } \\
\text { as possible) }\end{array}$ & 25 & 71.4 \\
\hline 5 & Buy food on credit & 19 & 54.2 \\
\hline 6 & Finding food (such as vegetables) on their own in the forest / & 17 & 48.5 \\
\hline 7 & garden & 17 & 48.5 \\
\hline 8 & Buy in large quantities to make it cheaper & 15 & 42.8 \\
\hline 9 & Reducing the number of meals a day & 14 & 40 \\
\hline 10 & Prioritizing food to certain family members & 2 & 5.7 \\
\hline
\end{tabular}

The first strategy is the strategy most widely used by households, namely by reducing the portion of food or eating that is not usually done by households, namely by reducing the frequency or amount of food. Related to this strategy, some households also prefer to save food so that food availability can be fulfilled within a certain period of time. The second strategy adopted by households is that they prefer to buy food that is cheaper (substitute), compared to those that are expensive or that have better quality and quantity of food. The third strategy that is used by households is to switch staple foods (such as from rice to cassava). Related to the fourth strategy, namely they only cook what food / food is available at home (eat only what is available). The fifth strategy is buying food on credit, this happens when households no longer have money and their food availability runs out, so they prefer to buy food on credit such as borrowing at certain stalls with a mutually agreed time limit. The sixth strategy carried out by households in coastal communities in Lantagi Village is to find their own food (such as vegetables) in the forest / garden to reduce expenditure costs. The seventh strategy taken is to buy in large quantities so that it is cheaper, in this strategy there are only 17 respondents because most households do not have the money to buy large quantities, but when their economic conditions improve, they used to buy in large quantities to make it cheaper. The eighth strategy is to borrow food / receive assistance from neighbors and families, in this case only a small proportion use this strategy, they prefer to carry out the previous strategies listed above. The ninth strategy that is carried out by households is to reduce the number of meals in a day, for example, reducing the number of meals a day to two times a day or even once a day. Whereas for the last strategy or the tenth strategy carried out by households is to prioritize food to certain family members, the purpose of this strategy is that parents prioritize children before themselves as parents.

Table 8 shows that the food-related strategy to overcome food shortages in Lantagi Village, most of the respondent households are on the strategy of reducing food portions and buying cheaper foodstuffs (substitution) and respectively (77.1 percent). Meanwhile, the lowest is in the strategy of prioritizing food to certain family members (5.7 percent). For the strategy of switching staple foods (such as from rice to cassava) is the second most widely used strategy, namely (74.2 percent), then 
followed by the strategy of cooking what food / food is available at home (eating as little as possible) of (71.4 percent).

The food security condition of the respondent's household in Lantagi Village is in a food security status that is experiencing food insecurity, this is because most of the households are below the poverty line, so there is a need for strategies to be carried out related to food to be able to maintain their survival. poverty is the inability of an individual to meet the minimum basic needs for a decent life (both food and non-food) (Nasution et al., 2018).

The condition of the so-called poor people can be determined based on their income ability to meet the standard of living (Irwansyah, 2016). In principle, the standard of living in a society is not only sufficient for the need for food, but also for the fulfillment of the needs for health and education. Adequate residence or settlement is one of the standard of living or welfare standards of the community in an area.

\section{Strategies Related to Household Income or Expenditures}

Most of the causes of household food insecurity status in Lantagi Village are influenced by household poverty(Sari \& Adi, 2016) and economic conditions(Titaley et al., 2020). Poverty is closely related to household income and expenditure(Islambay \& Aedy, 2017). The ability of income to meet basic needs based on certain price standards is low, so it does not guarantee that the standard of quality of life in general is fulfilled. Low income and uncertain sources of income from coastal communities are one of the causes of the ability of coastal communities to meet their daily needs(Widodo, 2011).

A household is indicated as having low income if the household expenditure on food to total expenditure is greater than non-food expenditure. The smaller the percentage of food expenditure to the total household expenditure, the more prosperous the household is(llham \& Sinaga, 2007). The level of household expenditure consists of expenditure on food and non-food, where the needs for the two expenditures are different. When the income earned is limited, the household will be more concerned with the need for food consumption, so that in low-income groups it will be seen that most of their income is used to buy food. So in this case there needs to be a strategy to overcome economic pressures (Feil, 2012) related to income or expenditure that must be done by respondent households in Lantagi Village in meeting their food consumption needs. According to Elder 1992.

Table 9. Strategies for Overcoming Food Deficiency Related to Household Income or Expenditure

\begin{tabular}{clcc}
\hline No. & Income or Expenditure Related Strategies & $\begin{array}{c}\text { Amount } \\
\text { Respondents }\end{array}$ & $\begin{array}{c}\text { Percentage } \\
(\%)\end{array}$ \\
\hline 1 & Reducing cigarette consumption & 23 & 65.7 \\
\hline 2 & Borrow money from family / neighbors & 21 & 60 \\
\hline 3 & Doing odd jobs & 18 & 51.4 \\
\hline 4 & Do not donate at family functions & 16 & 45.7 \\
\hline 5 & Selling domestic livestock & 14 & 40 \\
\hline 6 & Using savings & 4 & 11.4 \\
\hline 7 & When sick, go to a traditional doctor & 4 & 11.4 \\
\hline 8 & Not giving pocket money to children & 3 & 8.5 \\
\hline
\end{tabular}

Strategies for overcoming household food for coastal communities in Lantagi Village related to household income and expenditure vary widely, ranging from reducing cigarette consumption to not giving pocket money to children, which consists of eight (8) strategies. The first strategy that is most widely used is to reduce cigarette consumption, for example, from the consumption of one pack per day of cigarettes being reduced to half a pack per day, but there are also some who move from cigarettes that are expensive to smoking which are cheaper. The second strategy used by households is to borrow money from family / neighbors, namely if the household no longer has money, which is for a mutually agreed period of time. The third strategy is to do side jobs such as motorcycle taxis, construction workers, coconut climbers and others. The fourth strategy, namely Not donating during family events, this strategy is also used when households are in financial crisis, so they are forced not to donate. The fifth strategy is to sell domestic livestock such as native chickens. The sixth strategy that is used by households is to use savings, however this strategy is slightly carried out by households because most respondents do not have savings so that it has a big effect on household food, because when there is a lot of savings, the ability to buy food is very high and vice versa when saving little or no food purchasing power decreases, which can lead to food insecurity. The seventh strategy that is mostly carried out by households is, When sick, go to a dukun and only 
use traditional medicine. This strategy is claimed because households do not have money to go to hospital so they are forced to use this strategy. Meanwhile, the last strategy that was carried out by households at least was not giving pocket money to children, this really happens when the household no longer has any money at all. But there are also parts of this strategy that is carried out by households, such as reducing pocket money for children, for example, reducing an allowance of five thousand rupiah per day to two thousand rupiah per day. Meanwhile, the last strategy that was carried out by households was not giving pocket money to children, this really happens when the household no longer has any money. But there are also parts of this strategy that is carried out by households, such as reducing pocket money for children, for example, reducing an allowance of five thousand rupiah per day to two thousand rupiah per day. Meanwhile, the last strategy that was carried out by households at least was not giving pocket money to children, this really happens when the household no longer has any money at all. But there are also parts of this strategy that is carried out by households, such as reducing pocket money for children, for example, reducing an allowance of five thousand rupiah per day to two thousand rupiah per day.

Table 9 shows that most of the strategies related to household income or expenditure are in the strategy of reducing cigarette consumption by 23 respondents ( 65.7 percent) and borrowing money from family / neighbors as many as 21 respondents with a percentage of 60 percent. Then there were 18 respondents (51.4 percent) who did side jobs, did not contribute to family events as many as 16 respondents (45.7 percent), andSelling domestic livestock by 14 respondents (40 percent). Meanwhile, 4 respondents (11.4 percent) used their savings when they were sick. None of the respondents sold assets / jewelry owned, borrowed money from traders or credit takers and reduced education costs.

\section{CONCLUSIONS}

Based on the results of research on Coping Strategy Analysis in Overcoming Household Food Shortages in Coastal Communities in Lantagi Village, Kulisusu District, North Buton Regency It can be concluded that coastal community households in Lantagi Village in overcoming food / food shortages, the main strategy carried out related to food is to reduce the frequency of eating and buy cheaper foodstuffs with each percentage of $77.1 \%$. Meanwhile, the main household strategy related to income or expenditure is to reduce cigarette consumption by $65.7 \%$ and borrow money from family / neighbors by $60 \%$.

\section{REFERENCES}

Fatimah, E. (1995). Beberapa Faktor yang Mempengaruhi Alokasi Pengeluaran dan Tingkat Konsumsi Pangan Keluarga (Studi Kasus di Kelurahan Tanah Sareal, Bogor). Institut Pertanian Bogor. Bogor.

Hanum, N. (2017). Analisis Pengaruh Pendapatan Terhadap Perilaku Konsumsi Mahasiswa Universitas Samudra di Kota Langsa. Jurnal Samudra Ekonomika, 1(2), 107-116.

Hariyani, K. (2016). Analisis Pola Konsumsi Pangan Rumah Tangga Miskin. Skripsi. Program Studi Agribisnis. Fakultas Pertanian Universitas Sumatera Utara. Medan.].

llham, N., \& Sinaga, B. M. (2007). Penggunaan pangsa pengeluaran pangan sebagai indikator komposit ketahanan pangan. SOCA: Jurnal Sosial Ekonomi Pertanian.

Irwansyah, L. (2016). Kemiskinan, Keluarga Dan Prostitusi Pada Remaja. Psychology and Humanity, 2, 19-20.

Islambay, M. F., \& Aedy, H. (2017). Studi Faktor-Faktor Yang Mempengaruhi Tingkat Kemiskinan Di Desa Boro-Boro Kecamatan Ranomeeto Kabupaten Konawe Selatan. JEP (Jurnal Ekonomi Pembangunan), 7(2), 72-86.

Karmini, N. L., \& Erwin, P. P. (2012). Pengaruh pendapatan, jumlah anggota keluarga, dan pendidikan terhadap pola konsumsi rumah tangga miskin di Kecamatan Gianyar. E-Jurnal Ekonomi Pembangunan Universitas Udayana, 1(1), 44411.

Kuwornu, J. K., Suleyman, D. M., \& Amegashie, D. P. (2013). Comparative analysis of food security status of farming households in the coastal and the forest communities of Central Region of Ghana. Asian Journal of Empirical Research, 3(1), 39-61.

Laoh, O. E. H., \& Tangkere, E. G. (2018). Analisis Pendapatan Dan Konsumsi Masyarakat Pesisir Pantai (Studi Kasus: Di Dusun Rarumis Desa Karor Kecamatan Lembean Timur). AGRISosioekonomi, 14(1), 73-80.

Lewaherilla, N. E. (2002). Pariwisata Bahari Pemanfaatan Potensi Wilayah Pesisir dan Lautan. Makalah Falsafah Sains, 702. 
Limi, M. A. (2015). Pengaruh Langsung dan Tidak Langsung Faktor Produksi Terhadap Produksi dan Pendapatan Usahatani Padi Sawah Di Kecamatan Konda Kabupaten Konawe Selatan. Prosiding Seminar Nasional Agribisnis,

Massalinri, M., Ahmad, A., \& Masruhing, B. (2017). Pola Produksi Dan Konsumsi Pangan Pada Daerah Pesisir Di Kabupaten Sinjai Provinsi Sulawesi Selatan. Agrominansia, 2(2), 129-137.

Nasution, D. Q., Yulmardi, Y., \& Hardiani, H. (2018). Studi tentang kemiskinan di Kabupaten Batang Hari dan Kabupaten Muaro Jambi. E-Jurnal Perspektif Ekonomi Dan Pembangunan Daerah, 7(2), 79-90.

Natalia, M., \& Alie, M. M. (2014). Kajian Kemiskinan Pesisir di Kota Semarang (Studi Kasus: Kampung Nelayan Tambak Lorok). Teknik PWK (Perencanaan Wilayah Kota), 3(1), 50-59.

Prajnaparamita, K. (2018). Perlindungan Tenaga Kerja Anak. Administrative Law \& Governance Journal, 1(2), 215-230.

Sabono, J. S., Girsang, W., \& Thenu, S. F. (2019). Modal Sosial Dan Kemiskinan Di Desa Kilmasa, Kecamatan Kormomolin, Kabupaten Maluku Tenggara Barat (Studi Kasus: Kelompok Tani Bawang Merah Di Desa Kilmasa). Agrilan: Jurnal Agribisnis Kepulauan, 6(1), 17-33.

Sari, F. M. W., \& Adi, A. C. J. M. G. I. (2016). Ketahanan Pangan Dan Coping Strategy Rumah Tangga Di Pulau Terisolir Gili Labak, Kabupaten Sumenep, Madura. 11(2), 153-159.

Shariff, Z. M., \& Khor, G. L. (2008). Household food insecurity and coping strategies in a poor rural community in Malaysia. Nutrition research and practice, 2(1), 26-34.

Sofianto, A. (2018). Poverty Prevention Need in the North Coast of Central Java Province. Jurnal Penelitian Kesejahteraan Sosial, 16(2), 185-194.

Sumarsono, H., \& Muslikah, S. (2017). Indegenous Ekonomi Pembangunan Daerah. Penerbit Gunung Samudera [Grup Penerbit PT Book Mart Indonesia].

Titaley, C., Sallatalohy, N. M. a., \& Adam, F. P. J. a. (2020). Status Ketahanan Pangan dan Faktor Sosio-Ekonomi pada Masyarakat Pesisir Kabupaten Buru Selatan. agriTECH, 40(1), 1-12.

Wahyuni, S., Pradhanawati, A., \& Hidayat, W. (2015). Pengaruh Tingkat Pengalaman Berwirausaha, Produktivitas Dan Inovasi Terhadap Pengembangan USAha Kulit Lumpia (Studi Kasus Pada UMKM Kulit Lumpia Di Kelurahan Kranggan Kota Semarang). Jurnal Ilmu Administrasi Bisnis, 4(1), 263-274.

Widiastuti, A. (2018). Pengaruh Pendidikan, Jam Kerja, dan Pengalaman Kerja Terhadap Pendapatan Tenaga Kerja Lansia. Jurnal Pendidikan dan Ekonomi, 7(3), 253-262.

Widodo, S. J. H.-A. (2011). Strategi nafkah berkelanjutan bagi rumah tangga miskin di daerah pesisir. 10(1). 